\title{
Comments about gifted students and they adjustment in the scholar Brazilian model
}

\section{Comentários sobre alunos precoces e seu ajustamento no modelo escolar brasileiro}

\author{
Mariana Vieira-Dias ${ }^{1 *}$, Tales Alexandre Aversi-Ferreira ${ }^{2}$
}

\begin{abstract}
In general, the brain and metabolism development are associated with biological logic in a similar pattern in childhood. The frontal lobe development occurs in children mainly from four to seven years old, the time in which the prefrontal area presents high growth, however, brain development in some cases could be precocious. Then, educational actions must be initialized as far as possible in order to not neglect a possible gifted student. Then, the purpose of this critical review is to study the high abilities. Lack of studies and policy for the treatment of gifted children in Brazil creates a waste of talents to support society. Gifted children in Brazil seem to suffer discrimination and attend schools unprepared to receive and to direct their high abilities.
\end{abstract}

Keywords: Gifted, Education, Precocity.

\section{RESUMO}

Em geral, o desenvolvimento do cérebro e do metabolismo estão associados à lógica biológica. $\mathrm{O}$ desenvolvimento do lobo frontal ocorre principalmente em crianças de quatro a sete anos, época em que a área pré-frontal apresenta alto crescimento e começa a controlar os estados de atividade que permitem o trabalho intelectual inicial, no entanto, em alguns casos, o desenvolvimento do cérebro pode ser precoce. Então, o objetivo desta revisão crítica é estudar as altas habilidades de alunos talentosos no Brasil e sua relação com o ensino praticado no país. A falta de estudos e políticas para o tratamento de crianças superdotadas no Brasil gera um desperdício de talentos que poderia beneficiar a sociedade. Essas crianças parecem sofrer discriminação e frequentam escolas despreparadas para receber e direcionar suas altas habilidades.

Palavras-chave: Superdotados, educação, precocidade

\footnotetext{
${ }^{1}$ Universidade Federal de Minas Gerais.

*E-mail: correspondente@autor.com

${ }^{2}$ Universidade Federal de Alfenas
} 


\section{INTRODUÇÃO}

The age of children in schools was defined considering the studies from Herbart, that organized subjects in function of mental and pedagogic structures, based on psychological analysis (HERBART, 2010) and also on Pestalozzi. Posteriorly, these studies were partly corroborated by Piaget, but not by Vygotsky (VYGOTSKY, 1991).

The subjects and contents were associated with the brain development of children and teenagers according to the ability of understanding and seizure for information (HERBART, 2010), in a process followed worldwide.

In general, the brain and metabolism development are associated with biological logic in a similar pattern in childhood, with a few exceptions, while metabolic growing could present some differences, brain maturity is less variable (GALLAGHER, 2015). Consequently, school age is similar in many different cultures, and each discipline is associated with a certain level of mental development (VYGOTSK, 1991).

Indeed, frontal lobe development occurs in children mainly from four to seven years old, the time in which the prefrontal area presents high growth and begin to control the activity states that permit initial intellectual work (LURIA, 1937) such as listening, reading and writing, all very complex activities (LURIA, 1937).

In developing countries, teaching is unsatisfactory in general terms when considering new education methods (CASTRO; NISHIJO and AVERSI-FERREIRA, 2018), sometimes being based mainly on an overload of information in detriment of their motives and self-learning. Besides, their students receive hyperstimulation from the hodiern society, which generates agitation and stress (FREUD, 2014), a worse scenario when considering technology access for children.

The cited stimulus could be used correctly for improving motor and cognitive abilities; however, it should happen in a correct way, otherwise psychological symptoms as stress appear (OGEDA et al., 2016).

The analysis of cited information indicates a serious problem to normal children and teenagers, however, brain development in some cases could be precocious for at least a few people (GALLAGHER, 2015), generating the called early/gifted child.

This could be a problem both for precocious/gifted and normal children since it is not easy to measure the correct age in development; also, regular schools have no conditions to understand and/or attend early/gifted children in Brazil (MARTINS and CHACON, 2016), since the school curriculum was developed for typical aged people. 
Early/gifted children, despite their differences in individual development, present high intellectual abilities (MARTINS and CHACON, 2016).

In this way, most teachers have not enough training to discover these children and can't adequate teaching for improving their capacities/abilities (MARTINS and CHACON, 2016). It is worrisome since if the stimulation of these children does not occur at the correct time, they could present inadequate intellectual development.

Indeed, differently from other developing countries, in Brazil, the interest in gifted children is recent, mainly from 2008 which causes difficulties in correctly attending these kinds of students (CHACON and MARTINS, 2014). These students were placed into the group of Special Education in Brazil only in 2013 (BRASIL, 1996).

Notwithstanding, some proposals of teaching gifted students were performed before (MARTINS and CHACON, 2016).

An important aspect to be considered is the misunderstanding of concepts among gifted, early children and exemplary students, what could confuse the teachers in the recognition of the gifted ones, since earliness could or not be linked with gifted children, but all gifted are early children. In this way, if a child is precocious and not gifted, the precociousness will disappear after some time (MARTINS and CHACON, 2016).

However, educational actions must be initialized as far as possible in order to not neglect a possible gifted student (MARTINS and CHACON, 2016; CHACON and MARTINS, 2014). That means the purpose of this critical review is to study the high abilities, in which gifted pupils are a sub conjunct.

Recent studies in Brazil demonstrated that early/gifted children need special attention and present difficulties in learning some subjects (MARTINS and CHACON, 2016), and normal people present difficulties in even understanding what early/gifted students need help with.

On the other hand, the schools do not offer the necessary education for these students, generating a stress factor, demotivation, discouragement in developing abilities, in most cases due to the absence of challenges (MARTINS and CHACON, 2016) and difficulties for socio-emotional adaptations; indeed, the school seems to have an important role in students stress, as well as their families; a problem that could be added regarding gifted children's education is the individual differences presented by them (MAIA-PINTO and FLEITH, 2015). 
In this sense, basic neural knowledge seems to be very important for teachers to deal with normal and gifted pupils.

It is reasonable to question the conditions offered for gifted children in the student life in Brazil and, in light of the socio-cultural psychology mind theory (VYGOTSKY, 1991; LURIA, 1937), the gifted students need to develop in separated space.

Therefore, this review aims to analyze the situation of gifted children in schools, and to discuss a solution for these possible problems, considering social and behavioral aspects.

\section{MATERIAL AND METHODS}

For the purpose of this manuscript, were considered the indexers gifted pupils, education of gifted child and, education of gifted child stress, totalizing 338 articles from PubMed. For the Scopus database, for the same indexers were found 167 papers and from Scielo, 7, in a total of 512. From Scopus and Scielo no articles were found for education of gifted child stress.

After the verification of the duplicates, there were 78 articles remaining, these were studied and 19 were chosen according to the inclusion criteria that were the gifted child linked to the education and psychological subjects, including 1 thesis, and 8 books to generate the epistemological basis according to the objective of this manuscript. Books and papers about the basis of the mental activities were also incorporated. The exclusion criteria were the papers that versa only case study and outside for this manuscript scope.

Then, a total of 30 articles, books, and thesis were chosen for the purpose of this study.

\section{RESULTS}

The papers and books obtained from the mentioned keywords were discriminated and plotted in a graph (figure 1).

Figura 1 - Quantification of the types of articles used in this review. 


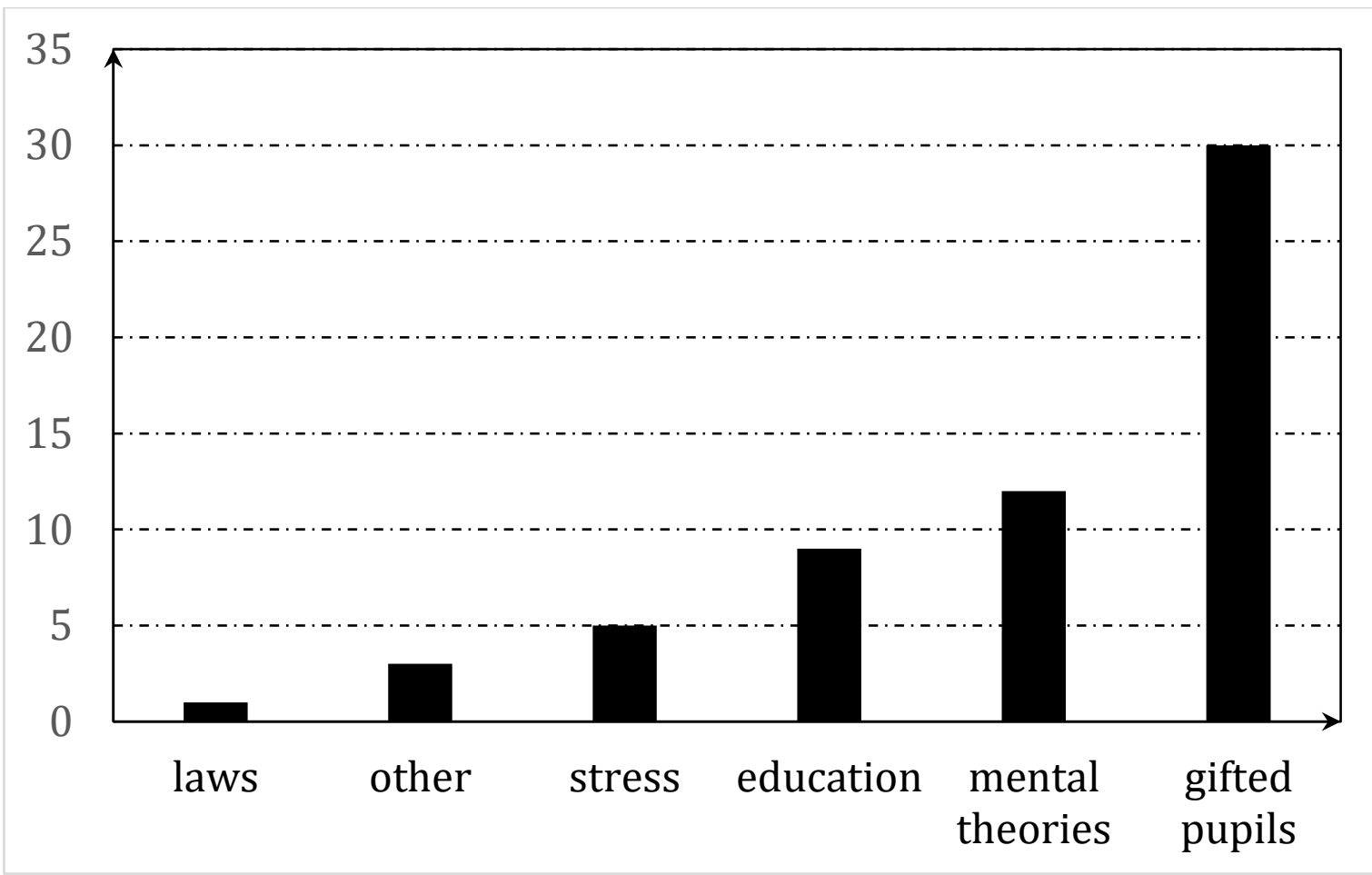

Source: DIAS; AVERSI-FERREIRA (2021).

About "education", "law" and "mental theories", many papers were used to base the epistemology in this review. The subjects from those papers were education methodology, rules of the National education in Brazil, child education, pedagogy, psychological bases of education, intellectual development, and active education from many different fields.

Specifically, about stress, some papers that cite oxidative effects of stress were used to ground the possible problems suffered by gifted pupils and psychological studies also were analyzed.

Finally, articles about gifted pupils were used according to the inclusion criteria versus history, psychological/neuropsychological and education studies in English, Spanish and Portuguese.

\section{DISCUSSION}

According to the data from scientific articles and books, few texts studied gifted students, showing the scarcity of this theme in Brazil.

None of the studies associated the mental theories with intellectual talent, mainly considering the social and behavioral problems linked to this condition in normal life and in the schools. 
In the United States, gifted people seem to receive a good social acceptance, except for those with high intelligence (GALLAGHER, 2015). However, when gifted children studied in the same class, they presented a social adjustment in a former research (KERSTETTER, 1952).

On the other hand, when gifted pupils were allocated together, typical intelligent students, the last ones preferred a social relationship themselves as well the gifted chose a social relation among them (MANN, 1957), however, in another study, the gifted were considered most popular among typical intelligent and low intelligent people (MILLER, 1956).

Accordingly, the gifted seem to be better socially adjusted when they live with people with identical intelligence, in general. In this way, if social problems could generate stress there is a strong clue that gifted people suffer stress when allocated in misfit environment.

The culture and social ambient in a country are evidently different in relation to others (VERAS and VERAS, 2011), accordingly, the popularity of the gifted pupils cited in studies in the USA could not be identical in other countries.

Similar studies were scarcely found in Brazil in terms of the social adequation of the gifted pupils in schools and society in general, with few exceptions (OGEDA et al., 2016).

Indeed, this situation needs to be solved under scientific analysis and as much as possible into practical research. This does not negligence the empirical/theoretical studies, even because the financial support and ethics proceedings could difficult the realization of these practical researches.

This kind of research is much more important when considering that the legislation about gifted children in Brazil is not correctly applied (PÉREZ and FREITAS, 2011) and that students will need special education, besides the need to offer specialized teaching training (OGEDA et al., 2016). However, this kind of service was offered in Brazil by Helena Antipoff in 1962 (ALENCAR and FLEITH, 2001) and developed by the Paulista University since 1972 teaching the gifted students in extra time and creating Support Center in Brasilia to assist Gifted pupils (NAS), working since 1975 (RANGINI and COSTA, 2011). 
Other centers were created but just the Center of Talent and Development (CEDET) made a work in national terms and more recent initiatives have done an effective work (RANGINI and COSTA, 2011).

In this way, since special education is guaranteed by Brazilian legislation (BRASIL, 1996) in all cases the separated classes are considered to have had an effect in teaching gifted children.

However, many researches defend that all students must be in the same space or class to privilege DIVERSITY (VILELA-RIBEIRO; BENITE and VILELA, 2013), what is indeed a common situation in Brazil since the classes are organized according to students' ages (MARTINS and CHACON, 2016).

The way of treatment of the gifted pupils in Brazil goes in a mismatch in relation to the US division of typical and gifted students, in terms of public education in Brazil where the class is mixed with typical and special students, with few exceptions, cited above.

In general, traditional education in Brazil supports disabled people (FREITAS, 2006), which poses a bigger dificult to support gifted students and wastes national talents.

On the other hand, the first step to support gifted child is to identify them, a task that teachers are scarcely prepared for in Brazil (PÉREZ and FREITAS, 2011; RANGINI and COSTA, 2011), sometimes because the new approaches in education started in school in the last few years and most of them continue teaching according to the conservative methods (CASTRO; NISHIJO and AVERSI-FERREIRA et al., 2018).

The same features of the gifted child need to be done carefully because aspects as liveliness could confuse teachers about giftedness that nowadays could be confused with ADHD (Attention-Deficit Hyperactivity Disorder) (ALVES e NAKANO, 2015).

From this information, it is reasonable to conclude that the most of school obviously built-in pedagogic practices by teachers, Brazil doesn't offer conditions for gifted students according to the US model, where this kind of child receives special treatment since a long time ago (MANN, 1957; MILLER, 1956) with rare exceptions. Indeed, the education for gifted children in Brazil is carried out by private initiative and in most school present aspects as acknowledging and exclusion in relation to giftedness (RANGINI and COSTA, 2011). 
The first part of the hypothesis this study is asking if Brazil offers conditions to teaching gifted children. The answer is negative with scarce exceptions (OGEDA et al., 2016).

The main causes are a maladjustment among the scholar ages and intellectual development; unprepared teachers and society, in general, to recognize giftedness (PÉREZ and FREITAS, 2011) and differentiate them from other behaviors, i.e., ADHD; rare presence of institutes/school prepared for teaching gifted students; priority to disabled students rather than gifted ones.

In consequence, it seems that stress and exclusion could be normal for gifted people in Brazil schools and society.

After the general comments about the situation of the giftedness in Brazil, an analysis confronting the giftedness problems with the socio-cultural philosophy seems reasonable for a better understanding of the problem.

The theory proposed by Vygotsky group in Russia about the approach of the mind development led to many books and papers (CASTRO; NISHIJO and AVERSIFERREIRA et al., 2018) sometimes emphasizing the teaching and mind/brain studies into the neuropsychology performed mainly by Luria (VYGOTSKY, 1991; LURIA, 1937; LURIA, 1996; LURIA; SIMERNITSKAYA and TUBVLEVICH, 1970; LURIA, 1979) could indicate some aspects to understand the problems involved in gifted pupils.

The book considered the one that proved the socio-cultural philosophy was written by Luria (LURIA, 1979) entitled The Making of Mind. Luria studied a group of people in villages and settlements in Uzbekistan and Khirgizia in Central Asia keeping in mind that the brain is part of a bigger biological and environmental system, i.e., the social organization acts on the mind construction.

According to this philosophy, the intellectual development of children occurs from a natural environment and social interactions, therefore education must integrate the learning and psycho-intellectual development, an aspect also studied by Piaget (PIAGET, 1966). Indeed, the normal scholar way cannot reflect real children's development.

Summarizing, in relation to learning, it depends on a correct mental organization offered by the education to development in children's historic human features (LURIA; SIMERNITSKAYA and TUBVLEVICH, 1970).

In Luria studies (LURIA, 1937; LURIA, 1979) the superior mental process is complex and could be understood as a summation of social, historic, environmental and 
brain features (LURIA; SIMERNITSKAYA and TUBVLEVICH, 1970). According to Vygotsky's purpose, it is necessary to lay hands of education for a correct and humanized orientation of the children.

If to consider that the environment is essential to the intellectual development, a class formed by identical people could increase the cognition aspects of the gifted students because the relationship with similar abilities stimulates each other, as occurs in Brazil in the few organizations for giftedness (RANGINI and COSTA, 2011) and vastly in the USA (GALLAGHER, 2015).

In this sense, the gifted pupils attending normal classes could be a source of stress and discouragement affecting social relationships with other people and for extension in family and to foment the exclusion feelings (RANGINI and COSTA, 2011) for this kind of students.

It is needed to analyze the rising of thinking among children for them to construct an internal activity (PIAGET, 1966), in this sense, a limited environment could be a dismay for the gifted.

The neural studies performed by Luria (LURIA, 1937) indicate that the brain could suffer changes in its structure in the obtention of learning. Accordingly, a scarce preparation and conduction of gifted people could generate damage for adequate development in these people's brains, i.e., it could be a limitation for intellectual growth.

Considering the socio-cultural philosophy plus the Luria posterior development into the neuropsychology the environmental, it is essential for the development of cognition in humans (LURIA, 1979), then it seems logical to conclude that gifted pupils need a special education for a correct development and to use this children's talents for favoring society with special attention for a humanistic targeting subsided by education.

It is more important to consider that gifted people present idiosyncratic learning (ROGERS, 2007), therefore, they need to receive the correct direction in this sense.

This humanistic support was cited by the socio-cultural group (LURIA; SIMERNITSKAYA and TUBVLEVICH, 1970), however, some authors claim that neuropsychology focuses on cognitive abilities and presents a lag in relation to motivation, creativity and artistic abilities (SILVA; ROLIM and MAZOLI, 2016). This could exist in modern neuropsychology or it is a misunderstanding of original neuropsychology and socio-cultural philosophy. 
It is a general knowledge that great minds generated important inventions and ideas for societal development while they suffered resistance from the typical intelligence, to the extent of Einstein commenting that the great spirits have always suffered opposition from mediocre minds.

Then not only the gifted children suffer problems in the adequation of their lives as they could suffer discrimination in society in general.

\section{CONCLUSION}

Lack of studies and policy for the treatment of gifted children in Brazil creates a waste of talents to support society with good work, ideas, inventions, philosophy, and sciences.

On the contrary, gifted children in Brazil seem to suffer discrimination and attend schools unprepared to receive and to direct their high abilities, due to the scarcity of teachers prepared for this special work and the failure of the pedagogical system, inter alia.

Gifted people need a different treatment deducted from socio-historic-cultural philosophy and educational nowadays system, still ingrained in the conservative methods. New education methods seem to fail for this special case since the integration of diversity has prioritized the students with low intelligence and physical/mental problems rather than gifted ones.

The preparation to receive and to train gifted students is an important educational aspect that is missing in Brazil and must be performed, considering the humanized and philosophical aspects of education, to conduct the cognitive features for these people.

According to the US, education and posterior previous Brazilian initiative for the gifted children plus deductions from Vygotsky group, special classes seem to be the ideal initial method for correct educational directions.

Indeed, other educational aspects must be considered, but it is necessary to begin in a specific environment that permits a good development of the intellectual, along with moral and ethical education. 


\section{REFERENCES}

ALENCAR, E. M. L. S; Fleith, D. S. Superdotados: determinantes, educação e ajustamento. São Paulo: EPU, 2001.

ALVES, R. J. R; NAKANO, T. C. A dupla excepcionalidade: Relações entre altas habilidades/superdotação com a síndrome de Asperger, transtorno de déficit de atenção e hiperatividade e transtornos de aprendizagem. Revista de Psicopedagogia, v. 32, n. 99, p. 346360, 2015.

BRASIL. Lei n. 9394, de 20 de dezembro de 1996. Que estabelece as diretrizes e bases da educação nacional. Brasília: Câmara dos Deputados, Edições Câmara, 2013.

CASTRO, S. K; NISHIJO, H.; AVERSI-FERREIRA, T. A. (2018). Neuroanatomy teaching: an example of active teaching applied to medical formation. American Journal of Educational Research and Reviews, v.3, n.37, 2018).

CHACON, M. C. M.; MARTINS, B. A. A produção acadêmica-científica do Brasil na área das altas habilidades/superdotação no período de 1987 a 2011. Revista Educação Especial, v. 27, n. 49 , p. 353-372, 2014.

FREITAS, S. N. Educação e altas habilidades/superdotação: A ousadia de rever conceitos e práticas. Editora UFSM, 2006. p. 109-125.

FREUD, J. K. Sobre O TDAH: Transtorno ou invenção? Ciência e Cultura, n. 66, n. 1), p. 5457, 2014.

GALLAGHER, J. J. Peer acceptance of highly gifted children in elementary school. Journal for the Education of the Gifted, v. 38, n. 1, p. 51-57, 2015.

GUENTHER, Z. C. Educação de bem dotados: alguns conceitos básicos. Psicopedagogia, v. 1, n. 2, p. 30-38, 2003.

HERBART, J. F. Pedagogia geral: deduzida da finalidade da educação. Lisboa: Fundação Calouste Gulbenkian. 2010.

KERSTETTER, L. M. A Sociometric Study of the Classroom Roles of a Group of Highly Gifted Children. New York University: School of Education, 1952.

LURIA, A. R. The working brain: A introduction to neuropsychology. New York: Basic Books, 1937.

LURIA, A. R. The Making of Mind. Cambridge: Harvard University Press. 1979.

LURIA, A. R. Higher cortical functions in man. New York: Basic Books. 1996.

LURIA, A. R; SIMERNITSKAYA, E. G; TUBYLEVICH, B. The structure of psychological processes in relation to cerebral organization. Neuropsychologia, v. 8, p. 13-19, 1970.

MAIA-PINTO, R. R; FLEITH, D.S. Percepção de alunos superdotados, mães e professores acerca da aceleração de Ensino. Interação em Psicologia, v. 19, n. 2, p. 187-198, 2015. 
MANN, H. How Real Are Friendships of Gifted and Typical Children in a Program of Partial Segregation? Exceptional Child, v. 23, n. 5, p. 199-201, 1957.

MARTINS, B. A; CHACON, M. C. M. Alunos precoces no ensino fundamental: quem são essas crianças? Revista Educação Especial, v. 29, n. 54, p. 233-246, 2016.

MARTINS, B. A; CHACON, M. C. M. Características de Altas habilidades/superdotação em alunos precoces:Um estudo de caso. Revista Brasileira de Educacao Especial, n. 22, v. 2, p. 189-202, 2016.

MILLER, R. V. Social Status and Socio-empathic Differences among Mentally Superior, Mentally Typical, and Mentally Retarded. Children. Exceptional Child, v. 23., n. 3, p. 114-119, 1956.

OGEDA, C. M; PEDRO, K. M; CRISTINA DA SILVA, R; MARTINS, B. A; OLIVEIRA KOGA, F; CHACON, M. C. Programa de atenção ao aluno precoce com comportamento de superdotação: uma proposta de enriquecimento extracurricular. Journal of Research in Special Educational Needs, v. 16, n. 1, p. 901-904, 2016.

PÉREZ, S. G. B. P; FREITAS, S.N. Encaminhamentos pedagógicos com alunos com Altas Habilidades/ Superdotação na Educação Básica: o cenário brasileiro. Educar em Revista, v. 27, n. 41, p. 109-124, 2011.

PIAGET, J. O nascimento da inteligência na criança. Rio de Janeiro: Editora Guanabara, 1966.

RANGINI, A. A; COSTA, M. P. R. A educação dos superdotados: história e exclusão. Revista Educação, v. 6, n. 2, p. 16-24, 2011.

Rogers, K. B. Lessons learned about educating the gifted and talented: A synthesis of the research on educational practice. Gifted Child Quarterly, v. 51, n. 4, p. 382-396, 2007.

SILVA, W. G; ROLIM, R. C; MAZOLI, W. H. Reflexões sobre processos neuropsicológicos de pessoas com altas habilidades/superdotação. Revista Interinstitucional de Psicologia, v. 9, n. 2, p. 195-210, 2016.

VERAS, E. Z; VERAS, D. B. Cultural differences between countries: The Brazilian and the Chinese ways of doing business. Journal of Innovation and Sustainability, v. 2, n. 2, p. 77 83, 2011.

VILELA-RIBEIRO, E. B; BENITE, A. M. C; VILELA, E. B. Sala de aula e diversidade. Revista Educação Especial, v. 26, n. 45, p. 145-160, 2013.

VYGOSTSK L. S. A Formação social da mente: o desenvolvimento dos processos psicológicos superiores. São Paulo: Martins Fontes, 1991.

Recebido em: 15/11/2021

Aprovado em: 10/12/2021

Publicado em: 15/12/2021 